Agro-Science Journal of Tropical Agriculture, Food, Environment and Extension Volume 15 Number 1 January, 2016 pp. 1-5

ISSN 1119-7455

\title{
LAYING PERFORMANCE, HAEMATOLOGY AND SERUM BIOCHEMICAL PROFILE OF HENS FED UNFERMENTED AND FERMENTED AFRICAN LOCUST BEANS
}

\author{
Akanji*, A.M., Fasina, O.E., Ogungbesan, A.M. and Adeleke, G.A. \\ Department of Animal Production, Olabisi Onabanjo University, Ayetoro Campus, Ogun State, Nigeria \\ *Corresponding author’s email: drakanjiadetayo@yahoo.com; Tel.:+ 2348034823340
}

\begin{abstract}
The study was carried out to compare the effects of unfermented and fermented African locust bean on laying performance, haematology and serum biochemical profile of hens in a twelve week feeding trial. The unfermented African locust bean (UALB) contained seeds that were dehulled and boiled in water, without going through fermentation. The fermented African locust bean (FALB) contained seeds that were dehulled, boiled in water and made to undergo natural fermentation for 4 days. One hundred, 40-week old, laying hens (Nera black) were randomly assigned to five dietary treatments in which UALB and FALB replaced soybean meal at 50\% and 100\% levels. Trypsin inhibitor (TI) activity was higher in the raw African locust beans (RALB), but no trace of the TI was contained in the UALB and FALB. However, higher residual amounts of tannin $(38.10 \mathrm{mg} / \mathrm{g})$ and phytate $(2.80 \mathrm{mg} / \mathrm{g})$ were obtained from the UALB. Egg weight and hen day production were significantly $(p<0.05)$ reduced in birds fed $100 \%$ UALB. Haemoglobin was similar ( $p>0.05$ ) across the groups of hens. The packed cell volume, red blood cells and white blood cells were significantly $(p<0.05)$ reduced in hens fed 100\% UALB. Alanine transaminase, aspartate transaminase and alkaline phosphatase were significantly $(p<0.05$ ) higher in birds fed $50 \%$ UALB and $100 \%$ UALB respectively. Marginal differences were however obtained in all the response indices between hens fed the control diet, 50\% FALB and 100\% FALB respectively. It was therefore concluded that fermentation was a better processing method for optimal utilization of Africa locust beans in diets of laying hens.
\end{abstract}

Key words: African locust beans, hens, performance, haematology, serum profile

\section{INTRODUCTION}

The high cost of animal protein has directed interest towards several leguminous seed proteins as potential sources of vegetable protein for human food and livestock feed. Among the plant species, grain legumes are considered as the major source of dietary proteins. They are consumed worldwide, especially in developing and under developed countries where consumption of animal protein may be limited as a result of economic, social, cultural or religious factors (Esenwah and Ikenebomeh, 2008). Prominent among the grain legumes in poultry feeding are the conventional soybean and groundnut, but these commodities are faced with dwindling local production especially in sub Saharan Africa, hence the need for continued exploration for underutilized grain legumes.

African locust bean is among the under-utilized grain legumes (Owoyele et al., 1987). According to Omafuvbe et al. (2004), the crude protein content of African locust beans is similar to those of cowpea, jack bean, lima bean and pigeon pea. The crude protein is a rich source of essential amino acids, minerals and vitamins. African locust bean had been successfully fermented for the production of food condiments in seasoning foods in Nigeria and other West African countries (Odunfa, 1986).

The potential of locust beans seed in the nutrition of humans and animals has been assessed (Eka, 1979; 1980). However, being a grain legume, it contains some antinutritional factors such as trypsin inhibitor, tannin, phytate and saponins. Several studies have been carried out by different investigators on improving the nutritive quality of African locust bean. The efficacy of fermentation at improving the nutritive quality of legumes has been noted (Muller, 1988; Omafuvbe et al., 2004). Improved performance traits, nitrogen retention and feed utilization of broilers fed fermented African locust bean as replacement of groundnut cake have been reported by Kolo (2000), Ayanwale and Ari (2002) and Dawodu (2009). Based on these findings, this study was carried out to compare the effects of fermentation of African locust bean on egg laying performance, haematological and serum biochemical indices of hens. 


\section{MATERIALS AND METHODS}

Raw African locust bean were sourced from local markets in Ibadan, South western Nigeria. The seeds were air- dried and sorted to remove unwanted particles. The procedural methods of fermentation as described by Omafuvbe et al. (2004) were used to process the African locust beans in this study. Two equal batches of the raw African locust bean were separately boiled in water for $12 \mathrm{hrs}$. Thereafter, the seeds were soaked further in the water used for boiling for another 12 hrs overnight. After soaking, excess water was drained off while the seeds were manually dehulled using the feet to press them in a large wooden mortar. Further removal of the seed coat was achieved by rubbing the seeds between the palms of the hand and washing with water. The dehulled seeds were then cooked for another 6 hrs. The first batch was subsequently oven-dried at this stage, bagged and labeled unfermented African locust bean (UALB).

The second batch of the cooked and dehulled seeds was put in a fermentor, and allowed to undergo natural fermentation for $72 \mathrm{hrs}$. Thereafter, the resulting cotyledons were oven dried, bagged and labeled fermented African locust bean (FALB).

\section{Chemical Analysis}

Analytical methods of AOAC (1984) were used to determine the crude protein, fibre, ash, ether extract and nitrogen free extract of the raw, unfermented and fermented African locust beans. Concentrations of trypsin inhibitor, tannin and phytate were determined using the procedural methods as outlined by Liener (1979), Dawra et al. (1988) and Maga (1983).

\section{Experimental Diets}

Five experimental diets (Table 1) were formulated in which UALB and FALB replaced soy bean meal at $50 \%$ and $100 \%$ levels. Minor adjustments were made in the other ingredients to make the diets isonitrogenous and isocaloric. Methionine and lysine were added to each diet to ensure that the amino acids were not limiting for growth.

\section{Experimental Birds}

A total of 100 laying hens (Nera black) of 40 weeks old were randomly allocated into five dietary treatment groups at 20 birds per group in a completely randomized design experiment. Each group was further subdivided into five birds per replicate. The birds were raised in battery cages and adequately dewormed in the first week of the experiment. Food and water were served ad libitum. At the end of the $12^{\text {th }}$ week, the experiment was terminated. Parameters used to measure the daily laying performance were feed intake, egg weight, feed conversion ratio and hen day production. The feed conversion ratio of each replicate was determined by dividing the feed intake by the egg weight.

\section{Analytical Measurements}

At 84 days, blood samples were collected from eight live birds per group (2 per replicate group) from the jugular vein. Blood samples for haematological analysis were collected into sterilized bottles containing ethylene diamine tetra acetic acid (EDTA) as anti-coagulant while those used for serum biochemical analysis were collected into tubes without EDTA and centrifuged before analysis. Packed cell volume (PCV) was determined using the microhaematocrit method while the haemoglobin content was determined with the cyanomethaemoglobin method (Apata, 1990). Red blood cell count was determined using the Neubauer haemocytometer, while alanine transaminase, aspartate trasaminase and alkaline phosphatase were determined with a spectrophotometer.

Table 1: Diets of birds fed unfermented and fermented African locust beans

\begin{tabular}{|c|c|c|c|c|c|}
\hline Ingredients & Control & $50 \%$ UALB & $100 \%$ UALB & $50 \%$ FALB & $100 \%$ FALB \\
\hline Maize & 48.60 & 49.00 & 49.50 & 50.50 & 50.50 \\
\hline Soybeans & 18.00 & 9.00 & - & 9.00 & - \\
\hline UALB & - & 9.00 & 18.00 & - & - \\
\hline FALB & - & - & - & 9.00 & 18.00 \\
\hline Wheat offal & 12.00 & 11.60 & 11.10 & 10.10 & 10.10 \\
\hline Palm kernel meal & 8.50 & 8.00 & 8.00 & 7.50 & 7.50 \\
\hline Fish meal & 1.50 & 2.00 & 2.00 & 1.70 & 1.90 \\
\hline Bone meal & 3.00 & 3.00 & 3.00 & 3.00 & 3.00 \\
\hline Oyster shell & 7.50 & 7.50 & 7.50 & 7.50 & 7.50 \\
\hline Salt & 0.20 & 2.00 & 2.00 & 2.00 & 2.00 \\
\hline Vitamins & 0.30 & 3.00 & 3.00 & 3.00 & 3.00 \\
\hline Lysine & 0.10 & 0.10 & 0.10 & 0.10 & 0.10 \\
\hline Methionine & 0.30 & 0.30 & 0.30 & 0.30 & 0.30 \\
\hline Total & 100.00 & 100.00 & 100.00 & 100.00 & 100.00 \\
\hline Calculated Crude Protein content (\%) & 17.11 & 16.49 & 16.50 & 16.56 & 16.82 \\
\hline Calculated Metabolizable energy $(\mathrm{kcal} / \mathrm{kg})$ & 2645.46 & 2644.17 & 2639.71 & 2637.34 & 2636.91 \\
\hline
\end{tabular}

UALB = Unfermented African locust Beans; FALB = Fermented African locust Beans,

0.30 premix supplied, per kilogram of diet: vitamin A, 12,000 IU; vitamin D3, 2,000 IU; vitamin E, 50 IU; vitamin B1, 1 mg; vitamin B2, 3 $\mathrm{mg}$; vitamin B6, $1 \mathrm{mg}$; vitamin B12, $10 \mu \mathrm{g}$; vitamin $\mathrm{K}, 2 \mathrm{mg}$; copper (cupric sulphate), $75 \mathrm{mg}$; nicotinic acid, $12 \mathrm{mg}$; pantothenic acid, 10 $\mathrm{mg}$; iron, $200 \mathrm{mg}$; cobalt, $0.5 \mathrm{mg}$; manganese, 40mg; zinc, $90 \mathrm{mg}$, iodine, $1 \mathrm{mg}$; selenium, $0.2 \mathrm{mg}$; calcium, $31.25 \mathrm{~g}$; sodium, $10 \mathrm{~g}$ 


\section{Statistical Analyses}

The experiment was carried out using the completely randomized design. The data were analyzed by analysis of variance. When analysis of variance indicated a significant treatment effect, means were separated using the Duncan multiple range test (Steel and Torrie, 1980).

\section{RESULTS AND DISCUSSION}

The analysis for proximate composition showed that raw African locust bean (RALB) had high crude protein $(\mathrm{CP})$ content (Table 2). The CP significantly $(\mathrm{p}<0.05)$ increased in the FALB, but marginally $(p>0.05)$ reduced in the UALB when compared to RALB. The ash, fat, and crude fibre contents were marginally reduced in both the FALB and UALB. The proximate composition obtained in the RALB is similar to the reports of Akoma et al., (2001), Omafuvbe et al. (2004) and Ari and Ayanwale (2012). The CP obtained in the RALB is close to the $30.6 \%$ reported by Eka (1979).The increase in the CP in the FALB is similar to the findings of Odebunmi et al. (2009) and Tortora et al. (2002) who attributed significant $(\mathrm{p}<0.05)$ increase in CP of fermented locust beans to structural proteins that are integral part of the microbial cells.

Results showing the antinutritional factors (ANFs) are presented in Table 3. Higher values of tannin $(43.5 \mathrm{mg} / \mathrm{g})$, phytate $(3.5 \mathrm{mg} / \mathrm{g})$ and trypsin inhibitor $(6.1 \mathrm{Tiu} / \mathrm{g})$ contents were obtained in the RALB. Trypsin inhibitor activity was destroyed in the UALB and FALB, while higher significant $(\mathrm{p}<$ 0.05 ) reductions in tannin, phytate and oxalate were obtained in the FALB. The tannin, phytate and trpsin inhibitor contents obtained in the RALB in this study are close to the values reported by Adeniran et al. (2013). The destruction of the trypsin inhibitor in both the UALB and FALB can be attributed to the cooking method used in this study. Moist heating has been established as a convenient means of eliminating trypsin inbitor and heamagglutinin activities in grain legumes (Emiola et al., 2003; Ologbobo et al., 1993; Udedibie and Carlini, 1998). Fermentation method of processing locust beans was able to considerably reduce tannin, oxalate, saponinns and phytate (Omafuvbe et al., 2004; Ari and Ayanwale, 2012) .

The egg laying performance is shown in Table 4. Feed intake was similar $(p>0.05)$ across the groups of hens. However, the egg weight $(\mathrm{EW})$ and hen day production were significantly $(\mathrm{p}<0.05)$ higher in hens fed $100 \%$ FALB, 50\% FALB and control based diets, respectively. The lowest EW was obtained in hens fed with 100\% UALB based diet. The feed conversion ratio (FCR) was higher ( $\mathrm{p}$ $<0.05$ ) in hens fed $50 \%$ UALB and $100 \%$ UALB based diets. The similarity in the feed intake across the groups of hens in this study can be attributed to the destruction of the trypsin inhibitor activity in both the UALB and FALB in the process of boiling the seeds. This observation is consistent with the reports of Ologhobo et al. (1993) and Akanji (2002) on similarities in feed intake of broiler chickens fed cooked jack bean-based diets and control diet. Akanji et al. (2007) fed raw jack beans and bambara nuts and reported significant negative correlations between feed intake and trypsin inhibitor intake. However, the reduction in the egg weight of the hens fed $100 \%$ UALB can be attributed to the likely increase in tannin and phytate intakes. The tendency of phytate and oxalate to make bivalent minerals and dietary protein unavailable for metabolism and utilization in chickens as reported by Israr et al. (2013) can be attributed to the lower egg weights obtained in the hens fed UALB based diets. Forbes et al. (1984) note that phytic acid chelates and thus makes unabsorbable such important minerals as zinc, iron, calcium and magnesium in monogastric animals.

Table 2: Dry matter proximate composition of raw, unfermented and fermented African locust beans

\begin{tabular}{llll}
\hline & RALB & UALB & FALB \\
\hline Crude protein (\%) & $31.94^{\mathrm{b}}$ & $30.81^{\mathrm{b}}$ & $36.34^{\mathrm{a}}$ \\
Ash (\%) & 3.04 & 2.91 & 2.96 \\
Ether Extract (\%) & 29.01 & 28.34 & 27.48 \\
Crude fibre (\%) & 2.94 & 2.61 & 2.56 \\
Carbohydrate (\%) & 25.08 & 25.34 & 19.77 \\
Dry matter (\%) & $92.01^{\mathrm{a}}$ & $90.01^{\mathrm{b}}$ & $89.11^{\mathrm{b}}$ \\
\hline RALB = Raw African Locust & beans, UALB $=$ Unfermented $^{\mathrm{b}}$
\end{tabular}

African Locust beans, FALB = Fermented African locust bean

Table 3: Anti-nutritional factors in the raw, unfermented and fermented African locust beans

\begin{tabular}{llll}
\hline & RALB & UALB & FALB \\
\hline Trypsin Inhibitor (Tiu/g) & 6.10 & - & - \\
Tannin (mg/g) & $43.50^{\mathrm{a}}$ & $38.10^{\mathrm{b}}$ & $\begin{array}{l}\mathrm{c}^{\mathrm{a}} \\
\text { Phytate (mg/g) }\end{array}$ \\
\hline
\end{tabular}

RALB = Raw African Locust beans, UALB = Unfermented African Locust beans, FALB - Fermented African locust beans

Table 4: Egg laying performance of hens fed unfermented and fermented African locust beans

\begin{tabular}{llllll}
\hline & Control & $50 \%$ UALB & $100 \%$ UALB & $50 \%$ FALB & $100 \%$ FALB \\
\hline FI (g/day) & 109.11 & 111.34 & 112.42 & 112.61 & 113.83 \\
EW (g) & $61.33^{\mathrm{a}}$ & $56.31^{\mathrm{c}}$ & $54.24^{\mathrm{c}}$ & $60.11^{\mathrm{a}}$ & $61.43^{\mathrm{a}}$ \\
FCR & $1.78^{\mathrm{c}}$ & $2.01^{\mathrm{a}}$ & $2.13^{\mathrm{a}}$ & $1.87^{\mathrm{b}}$ & 1.69 \\
HDP $(\%)$ & $78.62^{\mathrm{a}}$ & $71.31^{\mathrm{c}}$ & $65.33^{\mathrm{d}}$ & $75.13^{\mathrm{b}}$ & 0.97 \\
\hline
\end{tabular}

Means with different letters across the same row are significantly $(\mathrm{P}<0.05)$ different

$\mathrm{FI}=$ Feed intake; $\mathrm{EW}=$ Egg weight $; \mathrm{FCR}=$ Feed conversion ratio, $\mathrm{HDP}=$ Hen day production 
The FCR and lower hen day production in hens fed the 50\% UALB and 100\% UALB in this study can be attributed to poor utilization of the diets by the hens. Ebadi et al. (2005) reported negative effects of tannin on egg weight and egg production of laying hens fed sorghum. According to Ravindran et al. (1995) and Kornegay (1996), low ability of poultry to utilize phytate phosphorus is due to insufficient quantity or lack of intestinal phytase secretion. The inability of poultry to utilize phytate phosphorus results in the excretion of large amounts of phosphorus, posing an environmental concern in areas of intensive animal production. The phytate-bound phosphorus is unavailable to monogastric animals as they do not naturally have the phytase enzyme needed to break it down. Mustafa et al. (2012) reported the use of microbial phytase to improve egg weight, hen day production and egg quality of chickens fed diets rich in phytate. The effects of fermentation at reducing phenolic compounds, tannin and phytate contents of sorghum gruels were reported by Elicato (2006). This probably led to better egg weight and hen day production in birds fed FALB in this study.

The haematological indices and serum biochemical values are presented in Tables 5 and 6 . The haemoglobin values were similar $(p>0.05)$ across the groups of hens. The packed cell volume (PCV) was significantly $(\mathrm{p}<0.05)$ higher in hens fed control diet, and followed by those fed $50 \%$ FALB and $100 \%$ FALB. The lowest PCV value was obtained in hens fed $100 \%$ UALB. The red blood cells (RBC) were least of hens fed $50 \%$ UALB and 100\% UALB. The white blood cells (WBC) followed a similar pattern to that of the RBC. The highest $(\mathrm{p}<0.05)$ mean corpuscular volume (MCV) was obtained in hens fed control diet, while those fed 50\% FALB and $100 \%$ FALB followed in MCV values. The mean corpuscular heamoglobin $(\mathrm{MCH})$ values were similar $(\mathrm{p}>0.05)$ between hens fed control diet, 50\% FALB and $100 \%$ FALB based diets. The neutrophils were significantly $(\mathrm{p}<0.05)$ reduced in hens fed $50 \%$
UALB and 100\%UALB. The lymphocyte contents were similar $(p>0.05)$ across the groups of hens.

The alanine transaminase (ALT) was significantly $(\mathrm{p}<0.05)$ higher in hens fed $50 \%$ UALB and $100 \%$ UALB. Similar $(p>0.05)$ values of ALT were however obtained in hens fed control diet, 50\% FALB and 100\% FALB. The highest (p $<0.05$ ) aspartate trasaminase (ASP) was obtained in hens fed $100 \%$ UALB. The ASP value of hens fed $50 \%$ UALB diet was significant $(\mathrm{p}<0.05)$ than those of hens fed $100 \%$ FALB, 50\% FALB and control diet. Hens fed $50 \%$ and $100 \%$ FALB had similar ASP rate while those fed the control diet had the least ASP rate. The serum total protein was higher $(\mathrm{p}<0.05)$ in hens fed control diet, and followed by those fed $50 \%$ FALB and $100 \%$ FALB. The alkaline phosphatase was higher ( $\mathrm{p}<$ 0.05 ) in hens fed $100 \%$ UALB and $50 \%$ UALB diets. The increases in the RBC, PCV and WBC in hens fed FALB based diets are similar to the findings of Ari and Ayanwale (2012) when broiler chickens were fed with fermented African locust bean. The values of alanine transaminase, aspartate trasaminase, alkaline phosphatase and serum total protein obtained in the birds fed UALB based diets are similar to the values reported by Ologhobo et al.(1993),Aletor and Ogunyemi(1988) and Aletor and Fetuga (1984) who linked increased activities of hepatic transaminases in rats fed some raw legumes to high catabolism of amino acids and liver cell damage as a result of the inherent anti-nutritional factors.

\section{CONCLUSION}

Results of this study showed that egg laying performance; haematology and serum indices of hens were significantly better when FALB was included in their diets. The FALB had higher crude protein, and lower tannin, oxalate and phytate contents than UALB. The results also showed that fermentation is necessary for optimal utilization of dietary Africa locust beans by laying hens.

Table 5: Hematological profile of hens fed of hens fed unfermented and fermented African locust beans

\begin{tabular}{|c|c|c|c|c|c|c|}
\hline & Control & $50 \%$ UALB & $100 \%$ UALB & $50 \%$ FALB & $100 \%$ FALB & $\mathrm{SEM} \pm$ \\
\hline $\mathrm{Hb}(\mathrm{g} / \mathrm{dl})$ & 8.9 & 7.8 & 7.4 & 8.4 & 8.6 & 0.07 \\
\hline $\operatorname{PCV}(\%)$ & $33.4^{\mathrm{a}}$ & $29.1^{\mathrm{c}}$ & $26.7^{d}$ & $32.3^{b}$ & $32.8^{b}$ & 0.21 \\
\hline $\mathrm{RBC}\left(\mathrm{x} 10^{12} / 1\right)$ & $3.8^{\mathrm{a}}$ & $3.1^{\mathrm{b}}$ & $2.8^{\mathrm{c}}$ & $3.7^{\mathrm{a}}$ & $3.8^{\mathrm{a}}$ & 0.03 \\
\hline WBC (x109/1) & $2.8^{\mathrm{a}}$ & $2.2^{\mathrm{b}}$ & $1.8^{\mathrm{c}}$ & $2.7^{\mathrm{a}}$ & $2.6^{\mathrm{a}}$ & 0.01 \\
\hline MCV (fl) & $84.8^{\mathrm{a}}$ & $80.1^{\mathrm{d}}$ & $81.8^{c}$ & $83.5^{\mathrm{b}}$ & $83.9^{b}$ & 1.28 \\
\hline MCH ( pg/cell) & $28.9^{\mathrm{a}}$ & $25.8^{\mathrm{b}}$ & $25.1^{\mathrm{b}}$ & $27.3^{\mathrm{a}}$ & $27.9^{\mathrm{a}}$ & 0.18 \\
\hline Nitrophils (\%) & $58.1^{\mathrm{a}}$ & $53.4^{\mathrm{b}}$ & $52.8^{\mathrm{c}}$ & $56.1^{\mathrm{b}}$ & $56.4^{\mathrm{b}}$ & 0.98 \\
\hline Lymphocytes (\%) & 42.8 & 41.5 & 41.3 & 42.1 & 41.9 & 0.87 \\
\hline
\end{tabular}

Means with different letters in a row are significantly $(\mathrm{p}<0.05)$ different $) ; \mathrm{Hb}=$ Hemoglobin, $\mathrm{PCV}=$ packed cell volume, $\mathrm{RBC}=\mathrm{Red}$ blood
cells, $\mathrm{WBC}=$ White blood cells, $\mathrm{MCV}=$ Mean Corpuscular volume, $\mathrm{MCH}=\mathrm{Mean}$ Corpuscular Hemoglobin, $\mathrm{SEM}=\mathrm{Standard}$ error of mean

Table 6: Serum biochemical parameters in hens fed unfermented and fermented

\begin{tabular}{|c|c|c|c|c|c|c|}
\hline & Control & $50 \%$ UALB & $100 \%$ UALB & $50 \%$ FALB & $100 \%$ FALB & $\mathrm{SEM} \pm$ \\
\hline ALT (iu/l) & $30.8^{\mathrm{c}}$ & $32.8^{b}$ & $34.8^{\mathrm{a}}$ & $30.5^{\mathrm{c}}$ & $31.1^{\mathrm{c}}$ & 0.35 \\
\hline ASP (iu/l) & $212.1^{\mathrm{d}}$ & $265.7^{\mathrm{b}}$ & $276.8^{\mathrm{a}}$ & $222.4^{\mathrm{c}}$ & $223.7^{\mathrm{c}}$ & 3.89 \\
\hline ALP (iu/l) & $575.4^{\mathrm{c}}$ & $589.4^{\mathrm{a}}$ & $590.3^{\mathrm{a}}$ & $579.1^{\mathrm{b}}$ & $579.3^{\mathrm{b}}$ & 4.32 \\
\hline Total protein $(\mathrm{g} / \mathrm{dl})$ & $2.91^{\mathrm{a}}$ & $2.46^{\mathrm{c}}$ & $2.20^{\mathrm{d}}$ & $2.83^{b}$ & $2.84^{b}$ & 0.11 \\
\hline
\end{tabular}

Means with different letters across the same row are significantly $(\mathrm{P}<0.05)$ different 


\section{REFERENCES}

Adeniran, H.A, Farinde, E.O. and Obatolu, V.A. (2013) Effect of heat treatment and fermentation on antinutrients content of lima bean (Phaseolus lunatus) during production of Daddawa analogue. Ann. Rev. \& Res. in Bio., 3 (3), 256-266

Akanji, A.M. (2002). Enhancing the Utilization of Some Tropical Legume Seeds in Diets of Exotic Meattype and Egg-type Chickens. PhD thesis, University of Ibadan. pp. 103-109

Akanji, A.M, Ologhobo, A.D. and Emiola, I.A. (2007). Utilization of some raw tropical legumes in diets of exotic adult cockerels. J. Anim. Vet. Adv., 4, 485489

Akoma, O., Onuoha, S.A., Akoma, A.O. and Ozigis, A.A. (2001). Physico-chemical attributes of wine produced from the yellow pulp of Parkia biglobosa using traditional juice extraction technique. Nig. Food J., 19, 76-79

Aletor, V.A. and Fetuga, B.L. (1984). Effect of graded levels of raw lima bean (Phaseolus lunatus) on some liver enzyme activity in the rat. Nutr. Report Inter., 29, 565-570

Aletor, V.A. and Ogunyemi, O. (1988). Effect of varying level of fish meal substitution with soyabeans meal on certain serum metabolites and haematological indices. Am. Soybean Assoc., 44, 457-464

AOAC (1984). Official methods of analysis (14 ${ }^{\text {th }}$ ed.). Association of Official Analytical Chemists, Washington, D.C.

Apata, D.F. (1990). Biochemical, Nutritional and Toxicological Assessment of some Tropical Legume Seeds. Ph.D. Thesis, University of Ibadan, Nigeria. pp 111-115

Ari, M.M. and Ayanwale, A.A. (2012). Nutrient retention and serum profile of broilers fed fermented African locust beans (Parkia filicoide). As. Jour. of Agric. Res., 6, 129-136

Ayanwale, B.A. and Ari, M.M. (2002). Replacement value of Parkia filicoidea in broiler. J. Agric. Agric. Technol., 1, 42-52

Dawodu, F.A. (2009). Physico-chemical studies on oil extraction processes from some Nigerian grown plant seeds. Electron. J. Environ. Agric. Food Chem., 8, 102-110

Dawra, R.K., Makkar, H.S.P. and Singh, B. (1988). Protein binding capacity of microquantities of Tannins. Anal. Biochem., 170, 50-53

Ebadi, M.R. Pourreza J. Esmaeilkhanian, S. and Gharadaghi, A.A. (2005). Effect of sorghum tannin on egg quality and quantity of laying Pakistan. $J$. Nut., 12 (4), 496-499

Eka, O.U. (1979). Effect of fermentation on the nutrient status of locust beans. Food Chem., 5, 305-308

Eka, O.U. (1980). Effect of fermentation on the nutritional status of African locust beans. Food Chem., 6, 303-308

Elicato, T. (2006). Fermentation and enzyme treatment of tannin sorghum gruels: Effects on phenolic compounds, phytate and Fermentation and enzyme treatment of tannin sorghum gruels: Effects on phenolic compounds, phytate and in vitro accessible iron. Food Chem , 94, 3, 369-376

Emiola, I.A. Ologhobo, A.D. Adedeji, T.A. Oladunjoye, I.O. and Akanji, A.M. (2003). Performance characteristics of broiler chicks fed kidney beans as replacement for two conventional legumes. Moor J. Agric. Res., 4, 236-241
Esenwah, C.N. and Ikenebomeh, M.J. (2008). Processing effects on the nutritional and anti-nutritional contents of African Locust Bean (Parkia biglobosa Benth.) Seed. Pak. J. Nutr., 7 (2), 214-217

Forbes, R.M., Parker, H.M. and Erdman, J.W. (1984). Effects of dietary phytate, calcium and magnesium levels on zinc bioavailability to rats. J. Nutr., 114 (8), 1421-1525

Israr, B., Frazier, R.A. and Cordon, M.H. (2013). Effects of phytate and minerals on the bioavailability of oxalate from food. Food Chem., 141(3), 1690-1693

Kolo, E.S. (2000). Effect of Different Levels of Fermented Soyabeans (Glycin Max) Seeds on the Performance of Broilers. M. Tech. Thesis, Department of Animal Production, Federal University of Technology, Minna, Nigeria p. 124

Kornegay, E.T. (1996). Nutritional, environmental, and economic considerations for using phytase in pigs and poultry diets, In: Kornegay, E.T. (Ed.) Nutrient Management of Food Animals to Enhance and Protect the Environment, Chapter 18, pp. 277-302 (Boca Raton, FL, CRC Press)

Liener, I.E. (1979). Determination of antitryptic activity of soybean. J. Sci. Agric., 16, 602-609

Maga, J.A. (1983). Phytate: Its chemistry, occurrence, food interaction, nutritional significance and methods of analysis. J. Agric Food Chem. 30, 1-9

Muller, H.G. (1988). An Introduction to Tropical Food Science. Cambridge University Press, Cambridge, pp 112-118

Mustafa, S., Ahmed, G.O., Mehonet, D. and Ozcan, C. (2012). Egg production and calcium phosphorus utilization of laying hens fed diets supplemented with Phytase alone or in combination with organic acid. Italian J. Poult. Sci., 11 (3), 181-189

Odebunmi, E.O. Oluwaniyi O.O. and Bashiru M.O. (2009). Comparative proximate analysis of some food condiments. J. Applied Sci. Res., 6, 272-274

Odunfa, S.A. (1986). Legume-based Fermented Foods. CRC Press Inc., Boca Raton, FL., pp: 173-189

Ologhobo, A.D., Apata, D.E. and Oyejide, A. (1993). Utilization of raw jack bean (Canavalia ensiformis) and jack bean fraction in diets for broiler chicks. Brit. Poultry Sci., 34, 323-337

Omafuvbe, B.O., Falade, O.S., Osuntogun, B.A. and Adewusi, S.R.A. (2004). Chemical and biochemical changes in African locust bean (Parkia biglobosa) and melon (Citrullus vulgaris) seeds during fermentation to condiments. Pakistan J. Nut., 3, 140-145

Owoyele, J.A., Shok, M. and Olagbemiro, T. (1987). Some chemical constituents of the fruit pulp of Parkia clappertoniana as a potential industrial raw material. Sauana, 9 (2), 24-27

Ravindran, V., Bryden, W.L. and Kornagy, E.T. (1995). Phytates: occurrence, bioavaibility and implications in poultry nutrition. Poultry Avian Biol. Rev., 6, $125-143$

Steel, R.G.D. and Torrie, J.H. (1980). Principles and Procedures of Statistics: A Biometrical Approach. International Students Edition. Mcgraw Hill, New York, pp. 107-109

Tortora, G.J., Funke B.R. and Case, C.L. (2002). Microbiology: An Introduction. 7th Ed., Benjamin/Cummings Publishing Company, Inc., USA., p. 887

Udedibie, A.B.I. and Carlini, C.K. (1998). Questions and answers to edibility problems of the Canavalia ensiformis seeds - A review. Anim. Feed Sci. Tech., 74, 95-106 